\title{
DIGITAL MARKETING 5-GENERATION TECHNOLOGY AND ITS ACCEPTANCE BEHAVIOR
}

\author{
Muhammad Ismail \\ MS/M.Phil, Business Administration \\ Caretaker Officer: CM House, Punjab, Pakistan \\ Adjunct Faculty Member: (Project and Operation Management Dept.) \\ The Islamia University of Bahawalpur, Punjab, Pakistan \\ E-mail: ismailleghari14@gmail.com \\ (i) https://orcid.org/0000-0002-9437-9212 \\ K. M. Anwarul Islam \\ Associate Professor \\ Department of Business Administration \\ The Millennium University, Dhaka, Bangladesh \\ E-mail: anwarul@themillenniumuniversity.edu.bd \\ (i) https://orcid.org/0000-0002-5305-6724 \\ Muhammad Zohaib \\ MS, Department of Business Administration \\ Lecturer \\ Superior Group of Colleges, Multan, Pakistan \\ E-mail: muhammadzohaib4647@gmail.com \\ ib https://orcid.org/0000-0002-6664-9414

\section{Riaz Hussain} \\ MBA, Department of Business Administration \\ Loan Officer, Khushhali Microfinance Bank, Layyah Branch, Pakistan \\ E-mail: hussainriaz9856@gmail.com \\ (D) https://orcid.org/0000-0003-4215-350X \\ Muhammad Yasir Tahir \\ MS, Department of Business Administration \\ Regional Director, South Punjab Zone: Superior Group of Colleges, Pakistan \\ E-mail: rd_mtn@superior.edu.pk \\ (D) https://orcid.org/0000-0001-8107-0163

\section{Muhammad Ijaz} \\ BBA, Department of Business Administration \\ Bahauddin Zakariya University, Multan, Pakistan \\ E-mail: ijazhance71@gmail.com \\ Dhttps://orcid.org/0000-0002-0926-602X
}




\author{
Zuhaib Hassan \\ M.Com, Department of Finance \\ Loan Officer \\ Khushhali Microfinance Bank, Layyah Branch, Pakistan \\ E-mail: zuhaibhassan4155@gmail.com \\ https://orcid.org/0000-0003-1758-1756
}

Received: September 23, 2021 Accepted: November 12, 2021 Online Published: December 16, 2021

DOI: $10.46281 /$ ijmri.v5i1.1500

URL: https://doi.org/10.46281/ijmri.v5i1.1500

\begin{abstract}
Cumulative usage of digital media by customers, most of the companies are exploitation the digital marketing to get the access towards their target clients and markets. With the development of mobile technologies, mobile services have become an essential part of people's lives. After an ample research a series of advance experimentation and development, the mobile technology emerged and enters into more advance 5-G period. The purpose of this study is to examine various marketing strategies and investigate Pakistani consumers' approach towards the existing mobile services and classify the factors affecting their preferences towards 5-G acceptance. With a view to accomplish this study. A cross-sectional technique with the help of questionnaire was used to collect data. 15 to 45 years age people male \& female were our targeted audience from the different places of Multan city (Punjab province) Pakistan. 500 questionnaires were distributed and received $(n) 430$ which were completed by all aspects. $(F=58 \%) \&(M=42 \%) . S P S S,\left(22^{\text {nd }}\right)$ version used for data analysis. After the data analysis and discussion, $(r)$ correlation was retrospection that (DV), (IV) \& (MV) have a strong and positive relationship between each other. $\left(r^{2}\right)$ regression analysis also showed the confident, positive and durable relation among the all variables. Results show that the convenience, price, service quality, self-efficacy and value are the factors affecting consumers' acceptance in the presence of a moderator that is perceived usefulness. Suggested an extended TAM (Technology Acceptance Model) for checking consumer's behavior towards 5-G mobile services. Consumers should adopt the new technology and utilize it for the benefits of him/herself and for the community, nation and state.
\end{abstract}

Keywords: Digital, Suitability, Apparent Usefulness, Service Eminence, Self-Efficacy, Worth, TAM, Consumer Acceptance, 5-G, Acceptance Model.

\title{
INTRODUCTION
}

Prior to going to introduce the appropriate presentation of the computerized advertising of 3 age and its acknowledgment conduct. We will concentrate on that why advanced promoting is fundamental for the shoppers? How about we see that why computerized advertising applies for organizations?

\section{Why Digital Marketing?}

In the computerized promoting discussion $1 \mathrm{G}$ to ahead $5 \mathrm{G}$, with the expanding utilization of advanced media by shoppers, more organizations are utilizing computerized showcasing to arrive at their objective business sectors. Before the finish of 2010, the quantity of Web clients all over 
the planet will surpass 2 billion and this huge data traffic will keep on multiplying each $1-1.5$ years (Allsop et al., 2007). Advanced Advertising is the act of advancing items and administrations utilizing computerized circulation channels. Computerized Promoting is additionally alluded to as e-showcasing and incorporates advanced or web based publicizing, which conveys advertising messages to clients. Organizations are relied upon to spend more than $\$ 60$ billion on computerized promoting by 2011 (Ghinea \& Angelides, 2004). Arriving at purchasers through advanced media is viewed as the most encouraging field of improvement for advertising in the forthcoming decade (Buellingen \& Woerter, 2004).

\section{Revolution of $\mathbf{G}$ (Generations)}

Just, the "G" means "Age". While you connected to web, the rate of your web is relying on the marker strength that has been uncovered in images like $2 \mathrm{G}, 3 \mathrm{G}, 4 \mathrm{G}$ and so on right after to the sign bar on your home screen. Independently Age is clear as a bunch of phone network norms, which detail the specialized use of a specific cell phone framework. The speed upsurges and the innovation used to achieve that speed additionally changes. For instance, $1 \mathrm{G}$ (Age) offers $2.4 \mathrm{kbps}$, 2G (Age) offers $64 \mathrm{Kbps}$ and depends on GSM, 3G (Age) offers $144 \mathrm{kbps}-2$ MBPS while 4G (Age) offers $100 \mathrm{Mbps}-1 \mathrm{GBPS}$ and depends on LTE innovation that is quickest when contrasted with the past history of age (Kumar, 2004).

\section{BACKGROUND OF THE STUDY}

The current time discusses innovation. The need of advance and further developed innovation has been emerged because of progressive changes occurring in innovation. It has been arisen on the two scales huge and limited scope for example telephones which are presently days become savvy ones. The presentation of innovation appeared as ages and followed by first era. Zero age was the first to be presented around the world. The portable to-phone proportion has used the zero age. Original (1G) has been trailed by zero age and presented in year 1980 and alluded as principles of simple media transmission. The speed in original reaches from a modem of $28 \mathrm{~K}$ to a modem having $56 \mathrm{~K}$. Then, at that point, comes next age (2G) trailed by original in the year 1991. GSM Norms were the foundation of $2 \mathrm{G}$ innovation and became business and enjoyed a few benefits like short message administrations. The administrations identified with cell phones for example SMS administrations and media were presented by $2 \mathrm{G}$ innovation. However, the vast majority all over the planet is utilizing $2 \mathrm{G}$, the subsequent age has been overhauled as far as advantages and has been presented in a genuine of updated forms for instance $2.5 \mathrm{G}, 2.75 \mathrm{G}, 3 \mathrm{G}$ and $4 \mathrm{G}$.

Followed by $2 \mathrm{G}$ in the year 1998 the third-age innovation has been presented in the world of telecommunications. Apart from the $1 \mathrm{G}$ and $2 \mathrm{G}$ the acceptance of $3 \mathrm{G}$ technology has become critical, however it is further developed when contrasted with past one yet individuals are hesitant to embrace it. Beginning around 1998 3G has filled in as an adding apparatus in supporting web reachable administrations for example video talks and others. The exchange pace of $3 \mathrm{G}$ is more than past two ages that is no under $200 \mathrm{Kbit} / \mathrm{s}$. The figure beneath portrays the excursion of age in the realm of media transmission (Lee, Lee, \& Park, 2007). 


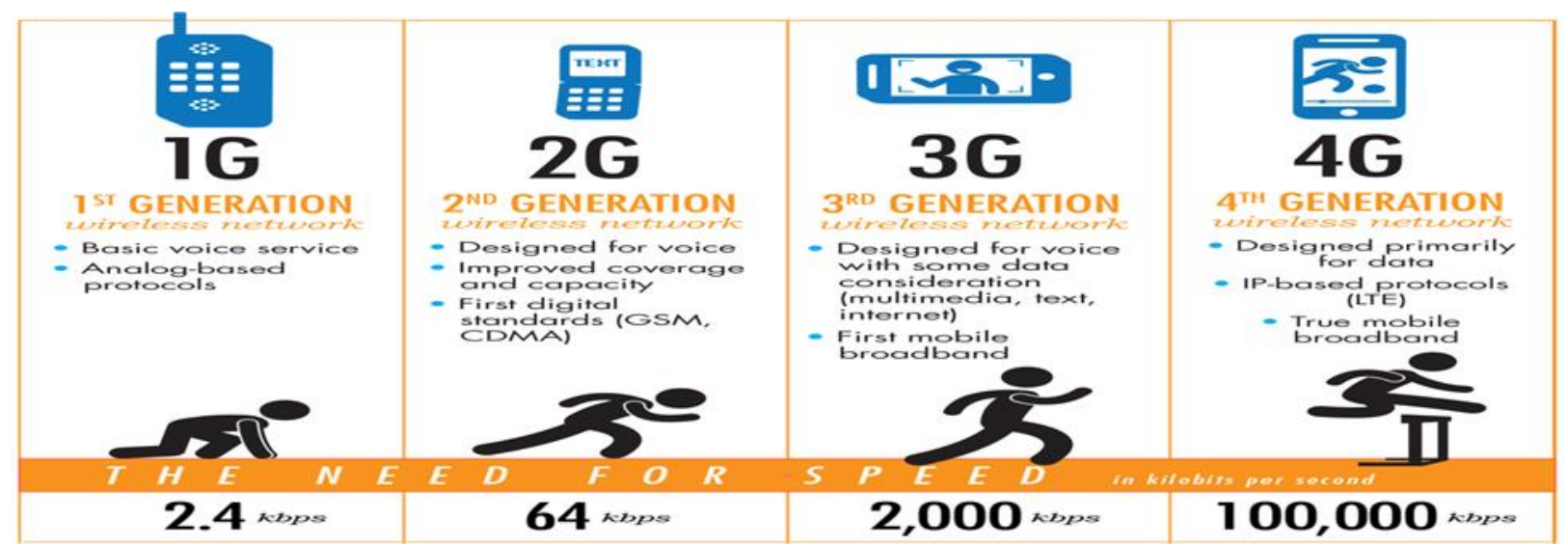

Figure 1. Beneath portrays the excursion of age in the realm of media transmission Source: (http://www.electronicsforum.com)

Table 1. Evaluation from $1 \mathrm{G}-5 \mathrm{G}$ Digital Development

\begin{tabular}{|c|c|c|c|c|c|}
\hline Features & $\begin{array}{c}\mathbf{1}^{\text {st }} \\
\text { Generation }\end{array}$ & $\begin{array}{c}\mathbf{2}^{\text {nd }} \\
\text { Generation }\end{array}$ & $\begin{array}{c}\mathbf{3}^{\text {rd }} \\
\text { Generation }\end{array}$ & $\begin{array}{c}\mathbf{4}^{\text {th }} \\
\text { Generation }\end{array}$ & $\begin{array}{c}\mathbf{5}^{\text {th }} \\
\text { Generation }\end{array}$ \\
\hline Start/Development & $1970 / 1984$ & $1980 / 1999$ & $1990 / 2002$ & 2000.2010 & $2010 / 2015$ \\
\hline Technology & $\begin{array}{c}\text { AMPS, } \\
\text { NMT, } \\
\text { TACS }\end{array}$ & GSM & WCDMA & $\begin{array}{c}\text { LTE, } \\
\text { WiMax }\end{array}$ & $\begin{array}{c}\text { MIMO, mm } \\
\text { Waves }\end{array}$ \\
\hline Frequency & $30 \mathrm{KHs}$ & $1.8 \mathrm{Ghs}$ & $16-2 \mathrm{GHz}$ & $2-8 \mathrm{GHz}$ & $3-30 \mathrm{Ghz}$ \\
\hline Bandwidth & $2 \mathrm{KBPS}$ & $14.4-64$ & $2 \mathrm{MBPS}$ & $\begin{array}{c}2000 \mathrm{MBPS} \\
-1 \mathrm{~GB}\end{array}$ & $1 \mathrm{GPBS}>$ \\
\hline Access System & FDMA & TDMA/CDMA & CDMA & CDMA & OFDM/BDMA \\
\hline Core Network & PSTN & PSTN & $\begin{array}{c}\text { Packet } \\
\text { Network }\end{array}$ & Internet & Internet \\
\hline
\end{tabular}

Source (http://net-informations.com/q/diff/generations.html)

\section{Main Research Problem}

Our principle research question is "Does the 5-G Innovation in Pakistan and its effect on purchaser conduct?" Other significant exploration questions are as per the following:

- What are the key factors that fundamentally sway Purchaser Acknowledgment of 5-G Innovation?

- Which variable is the best indicator of innovation acknowledgment prompting customer acknowledgment of 5-G?

\section{Problem Statement}

"What is the effect of 5-G Innovation Use in Pakistan on Purchaser Acknowledgment Conduct?" Remote correspondence innovation had been created keeping in view the huge development in different areas and nearly by each industry. Progression in new innovation has made ready for supporters of comprehend and utilize a greater amount of innovation. This comprehension of innovation brings about expanded interest by supporters. The resultant result is the rise of new 
applications for instance own stacking music, real time video sand gaming. The mix of $3 \mathrm{G}$ innovation and remote innovation brings about assorted administrations to clients of mobiles and has been used for portable systems administration worldwide. Global media transmission association has established $3 \mathrm{G}$ which is described to the IMT-2000. The data and correspondence obligations have been taken over by a specific organization of Joined Countries named as worldwide media transmission association (ITU). In Japan 3G organization has been initially presented by NTT DoCoMo for the business use. 3G administrations have outfitted the new age with an assortment of administrations to the individuals who venerate innovation. The pattern now days has been moved towards $3 \mathrm{G}$ and clients are getting a charge out of many advantages alongside assorted elements.

Above all 3G worked with purchasers to with an assortment of capacities especially data sharing has been completed by means of web openness paying little heed to overall setting imperatives which is exceptionally productive and advantageous. Up to this point when contrasted with different innovations $3 \mathrm{G}$ gives the higher speed. It is a direct result of $3 \mathrm{G}$ individuals are associated with their families and companions through visual correspondence by settling on video decisions at fast (Mun \& Hwang, 2003).

The mechanical progressions have made it need rather than a design. Clients can utilize it in various ways for occasions the downloading has made the youthful age to download music and easy to use gadgets. The sharing of reports has been made simple through messages. Third era has made it simple and faster to download records of each sort as one can download and introduce games. It is simple presently to gain admittance to data, all things considered, and make it accommodation for client to refresh oneself with the external world (Hill, Smith, \& Mann, 1987). Aside from different offices it offers a few types of assistance for example interactive media applications, tremendous systems administration and above all the endeavor to oversee clamor. Keeping in view the adaptability of administrations given by $3 \mathrm{G}$ however the noteworthy thing is the money related advantage is there. In such manner the explanation minute variance as far as cycle in the new forms of $3 \mathrm{G}$. Like $2.5 \mathrm{G}$.

There are not many variables which drove the way towards the need of $3 \mathrm{G}$ and can be called as downsides in past advancements.

One of the significant disadvantages was Helpless voice pitch, low battery life, zero security, lacking limit, low handoff unwavering quality, unfit to collect complex information (Lee, 2003).

\section{Objectives of Study}

The destinations of the review are given underneath:

- To really take a look at connection between administration characteristics, cost and saw esteem.

- To measure customer level of 3Gtechnology

- To dissect the roll of mediating variable, i.e., perceived usefulness.

\section{Scope of Study}

The extent of this review is to unmistakably characterize the elements influencing the buyer insight and which outer elements are viewed as the most helpful for acknowledgment and dismissal of $3 \mathrm{G}$ innovation. As 5-G innovation is being utilized generally all around the world and as such the extent of this review is likewise wide. 


\section{LITERATURE REVIEW}

There is general understanding that computerized media has incredibly affected the manner in which an advertiser arrives at the present purchaser. Computerized media alludes to electronic media that scatter data in advanced organizations (Ghinea \& Angelides, 2004). This incorporates any media accessible through PCs, cellphones, advanced mobile phones, or other computerized gadgets like advanced outside signs. The Web is an unmistakable setting of advanced showcasing. Computerized publicizing is a type of advancement that utilizes the Web for the express reason for conveying advertising messages. Computerized or web based publicizing has gone through remarkable development since its initiation in 1994 (Robinson, Wysocka, \& Hand, 2007).

By the July 2003, a million new clients were relied upon to use the stationary telephones as shop ones to observe live match, ready to settle on video decisions, and can check-mail, (Adams, Nelson, \& Todd, 1992), "3G is the one which is liable for this insubordination and new market. Remote hardware and portable applications in market have been over promoted. The origination of significant worth to the customer and to the purchaser isn't constantly disseminated through these advancements (Buellingen \& Woerter, 2004). To technologists, the response to all business emergencies is the innovation. Alternately, pessimists wrap up that remote versatility clarifications are weak for the endeavor until the $3 \mathrm{G}$ of remote form into a confirmed credibility.

Conduct prediction stayed one of the significant reasoning's of mental hypotheses. Among every one of the one more useful hypotheses assess TRA (hypothesis of contemplated activity) (Ajzen \& Fishbein, 1980; Ajzen \& Fishbein, 1975), SCT (social intellectual hypothesis) (Compeau \& Higgins, 1995a; (Ghinea \& Angelides, 2004), lastly the acknowledgment Model (Davis et al., 1989). It was once introduced by Davis et al. (1989), is subordinate from hypothesis of contemplated activity (Ajzen \& Fishbein, 1980; Ajzen \& Fishbein, 1975). The Acknowledgment Model is a social model that shows the forerunners of the embrace of data innovation (IT), and is thoroughly examined a vivacious apparatus for estimating the acknowledgment of new innovation by shoppers (Agarwal \& Prasad, 1999; Davis et al., 1989; (Lee, Lee, \& Park, 2007). The following is a clarification of Cap, which involves six factors which are outside factors, disposition, seen handiness, conduct expectation, seen usability and genuine utilization. I

Shows that client conduct is controlled by keenness' of handiness and the straightforwardness in utilizing the innovation (Yu et al., 2005), and different specialists likewise persuaded on this view point. Generally analysts like (Davis et al., 1989), and (Liang \& Wei, 2004). Technology Acceptance Model (TAT) has been utilized broadly to clarify the elements influencing acknowledgment of shopper in regards to 3G. It offers a substantial constitution to explain the client variation methodology of new educational items (Davis, 1985; Davis et al., 1989). Figure above exhibits the original Hat (Zhang \& Prybutok, 2005).

The fundamental target of this model is to build reason for following back the impact of outside develops on inside convictions, sentiments and plans. That suggests that there are two elements which clarifies the framework value sin much better way and considered as most significant one. One of the variable among six is seen value of innovation followed by the apparent usability. The model essentially measures the shopper's mentalities and feelings with respect to acknowledgment or reprimand of $3 \mathrm{G}$ innovation. Numerous researchers have taken care of business in various Asian nations similarly China, Malaysia, India and so on, to concentrate on the variables that affect customer embrace of $3 \mathrm{G}$ innovation and the iron sights around $3 \mathrm{G}$ administrations. In couple of studies hypothesis of arranged conduct has been contended (Adams et al., 1992), conceives and elucidates human conduct dynamically among various data advances. This hypothesis clarifies that one's real conduct is convinced by individual's conduct goal. Then 
again, Innovation Acknowledgment Model spotlights on two central point among six. Seen handiness is described to placing less power in specific work. In couple of studies (Adams et al., 1992), Cap fundamental develops don't completely look at the individual's arrangement towards innovation. Thus, in past examinations, the acknowledgment model has been expanded by different factors for example apparent energy, seen validity, similarity, trust, seen client asset, and dependability (Mun \& Hwang, 2003).

Already abundant exact work has utilized the acknowledgment model (Alch, 2000), further give that acknowledgment or dismissal towards innovation has been investigated utilizing diverse mental models for example TPB, TRA, and Cap which was stretched out for concentrating on the conduct of the shoppers towards data innovation. Among three Hat is the broadly adjusted model. In couple of studies it has been joined with extra outer factors and a tad it has been related with dispersal related factors for instance apparent advantages and social impact, (Compeau \& Higgins, 1995b). The Acknowledgment Model zeroed in on apparent handiness and saw usability straightforwardly appended to individual's aim towards utilizing an innovation and it further investigates the shopper dismissal or acknowledgment convinced by the conduct expectation of the buyer (Davis et al., 1989), dealt with end client embrace of interactive media portable administrations by amassing cost and speed of utilization to the Cap model. It has been investigated that apparent helpfulness, convenience, cost and speed of utilization are the main determinant so acknowledgment of multi supporters' training in burning-through portable information administrations (Ajzen \& Fishbein, 1975).

As per innovation acknowledgment model, outer factors influence the acknowledgment of 3G innovation administration. (Agarwal \& Prasad, 1999), named such factors as working with conditions which comprise of the sort of help give to people that impact their reception and utilization of the innovation. (Agarwal \& Prasad, 1999), further clarified working with conditions as "how much an individual accepts that a hierarchical and specialized foundation exists to help utilization of the framework". Subsequent to survey past investigations on $3 \mathrm{G}$ reception we have recognized a gathering of outside factors influencing $3 \mathrm{G}$ reception. In light of their significance to $3 \mathrm{G}$ innovation, the accompanying factors is chosen Administration quality, Comfort, PC selfadequacy, Seen esteem and Saw value/cost (Davis et al., 1989).

Table 2. Digital Marketing that Grabs Attention

\begin{tabular}{|l|l|l|}
\hline Sr. \# & Marketing Strategy & \% of Respondents \\
\hline 1 & Graphics & $73.4 \%$ \\
\hline 2 & Bright colors & $53.6 \%$ \\
\hline 3 & Interactive & $50.6 \%$ \\
\hline 4 & Personalization & $46.5 \%$ \\
\hline 5 & Simple, Professional layout & $43.1 \%$ \\
\hline 6 & Free (the word) & $28.5 \%$ \\
\hline
\end{tabular}

Notwithstanding the reality here $46 \%$ of the respondents said that personalization on a site catches their eye, personalization was not the best procedure in this undertaking. Hence, speculation 3 was not completely upheld. The computerized showcasing system that predominantly commands the notice of a Millennial is the utilization of designs. Respondents were requested to check out a rundown from site includes and select up to three elements that were probably going to catch their eye. Designs catch the consideration of $73 \%$ of the respondents. 
Around half of the respondents said that intelligent elements and brilliant shadings hold onto their consideration. A basic, proficient format catches the consideration of $43 \%$ of the respondents. As displayed in Table 3, the least eye catching component is the utilization of "free." Notwithstanding, "free" fills a need, as distinguished by the following study question, unconditional presents will incite rehash visits to a site.

\section{CONCEPTUAL FRAMEWORK}

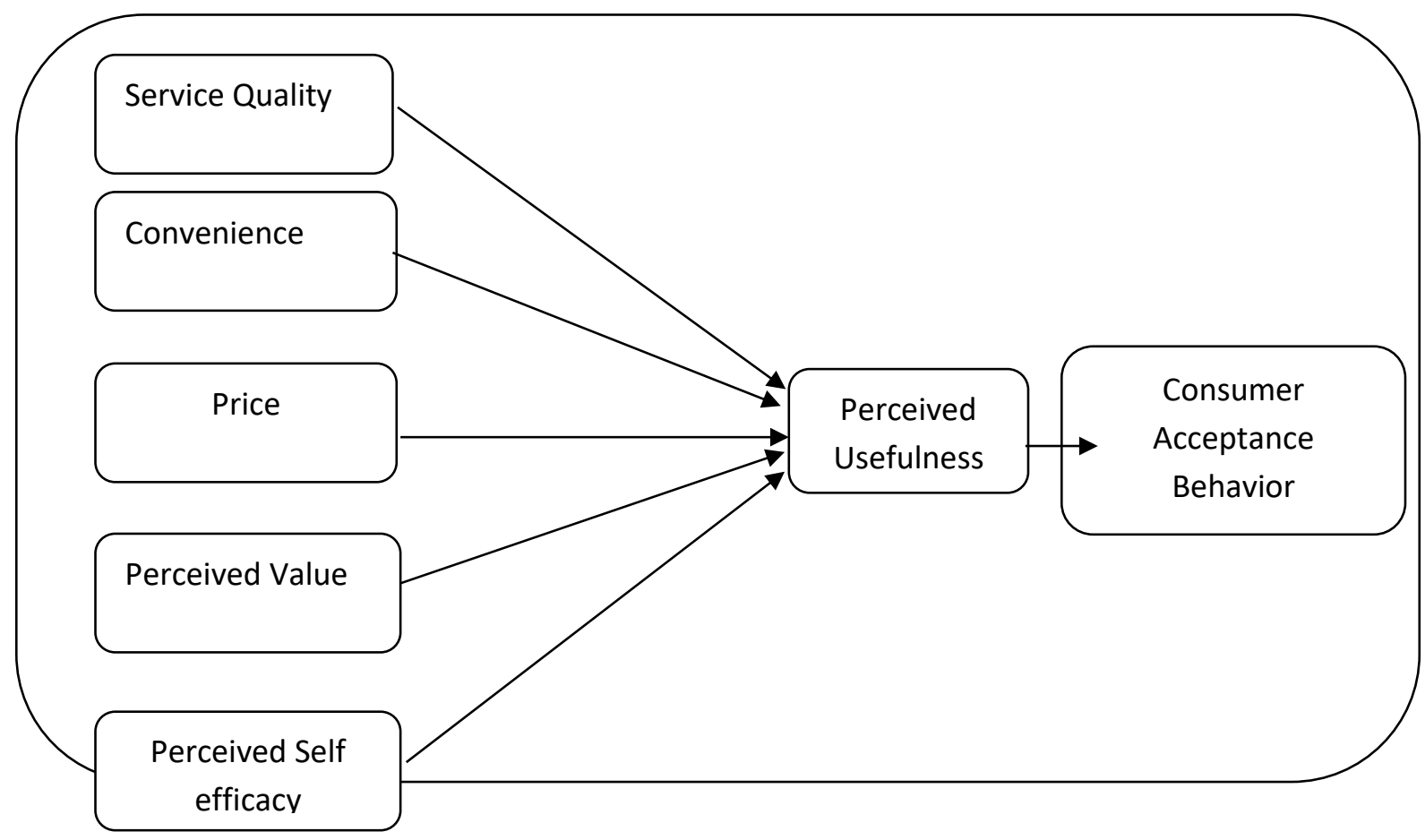

Figure 2. Conceptual model of the theoretical framework

\section{Hypothesis}

$\mathrm{H}_{1}$ : Service quality is significantly correlated to CAB with respect to MV Perceived usefulness. $\mathrm{H}_{2}$ : Convenience is significantly correlated to CAB with respect to MV Perceived usefulness. $\mathrm{H}_{3}$ : Price is significantly correlated to $\mathrm{CAB}$ with respect to MV Perceived usefulness.

$\mathrm{H}_{4}$ : Perceived Value is significantly correlated to CAB with respect to MV Perceived usefulness. $\mathrm{H}_{5}$ : Perceived Self efficacy has significant impact on CAB with respect to MV Perceived usefulness.

$\mathrm{H}_{6}$ : Perceived usefulness is significantly correlated to Consumer acceptance of 5-G

\section{Type of Research}

\section{RESEARCH METHODOLOGY}

The fundamental motivation behind the review is to actually look at the connection between service quality, price, perceived value, convenience, and computer self-efficacy and consumer acceptance in the presence of an intervening variable that is perceived usefulness. This momentum research subject are taken on from different investigations based on technology acceptance model i.e., TAM 


\section{Study Setting}

The review is directed in the crowded city Multan of Pakistan to really look at the conduct of buyers towards the $3 \mathrm{G}$ innovation. That it is cross sectional as it is directed in single edge of time.

\section{Unit of Analysis}

The point of the review is to analyze the connection between service quality, price, perceived value, convenience, and computer self-efficacy and consumer acceptance in the presence of an intervening variable that is perceived usefulness. Thusly, the unit to finals is in this review is normal end clients from various spaces of public Multan city.

\section{Sample and Technique}

A non-likelihood convenience sampling technique was taken on to draw the samples from the piece of the populace as it is cross sectional concentrate because of time imperative this technique has utilized.

\section{Instrument \& Data Collection Procedure}

Data has been gathered utilizing questionnaire poll. Questionnaire Polls were appropriated to various age gathering of individuals running between 15-45 years living in various spaces of Multan. The 500 surveys were circulated among the respondents and got (n) 430 which were totally, completely and filled by all aspects. As for gender greater part involves female establishing $58 \%$ and male were $42 \%$ of absolute legitimate reactions and responses.

\section{Frequency Distribution}

\section{DATA ANALYSIS}

Frequency dispersion has been performed in the wake of ordering the factors based on socioeconomics for example age, sex/gender, region/area, occupation and primary 5-G specialist organizations in the significant region picked.

Table 3. Frequency distribution based on gender

\begin{tabular}{|l|l|l|}
\hline Gender & Percent & Frequency \\
\hline Male & $42 \%$ & 181 \\
\hline Female & $58 \%$ & 249 \\
\hline Total & 430 & 430 \\
\hline
\end{tabular}

Table 4. Correlation between Variables

\begin{tabular}{|l|l|l|l|l|l|l|l|}
\hline \multicolumn{2}{|c|}{ Correlation Matrix } \\
\hline & & PU & PSE & PR & SQ & CNV & PV \\
\hline PU & Pearson Correlation & 1 & & & & & \\
\hline & N & 430 & & & & & \\
\hline PSE & Pearson Correlation & & 1 & & & & \\
\hline
\end{tabular}




\begin{tabular}{|c|c|c|c|c|c|c|c|}
\hline & & $.239^{*}$ & & & & & \\
\hline & $\mathrm{N}$ & 430 & 430 & & & & \\
\hline \multirow[t]{2}{*}{$\overline{\mathrm{PR}}$} & Pearson Correlation & $.458^{* *}$ & $.357^{* *}$ & 1 & & & \\
\hline & $\mathrm{N}$ & 430 & 430 & 430 & & & \\
\hline \multirow[t]{2}{*}{ SQ } & Pearson Correlation & $.451^{* *}$ & $.294^{* *}$ & $.751^{* *}$ & 1 & & \\
\hline & $\mathrm{N}$ & 430 & 430 & 430 & 430 & & \\
\hline \multirow[t]{2}{*}{$\begin{array}{l}\mathrm{CN} \\
\mathrm{V}\end{array}$} & Pearson Correlation & $.527^{* *}$ & $.750^{* *}$ & $.556^{* * *}$ & $.661^{* *}$ & 1 & \\
\hline & $\mathrm{N}$ & 430 & 430 & 430 & 430 & 430 & \\
\hline \multirow[t]{2}{*}{$\mathrm{PV}$} & Pearson Correlation & $.510^{* *}$ & $.773^{*}$ & $.643^{* *}$ & .343 & $.487^{* *}$ & 1 \\
\hline & $\mathrm{N}$ & 430 & 430 & 430 & 430 & 430 & 430 \\
\hline $\begin{array}{l}* * \\
\text { Cor }\end{array}$ & $\begin{array}{l}\text { elation is significan } \\
\text { ion is significant at }\end{array}$ & the & 1 leve & led). *. & & & \\
\hline
\end{tabular}

It has observed that every one of the factors are firmly co-identified with one another. This way all the substitute speculation has been acknowledged for the review.

\section{Regression Analysis}

The Relapse Investigation was utilized to observe the effect of autonomous variable on subordinate variable as the review is utilizing arbitrator so different relapses had been utilized as introduced.

Table 5. Regression Coefficient

\begin{tabular}{|c|c|c|c|c|c|}
\hline Model & \multicolumn{2}{|c|}{$\begin{array}{c}\text { Unstandardized } \\
\text { Coefficient }\end{array}$} & $\begin{array}{c}\text { Standardized } \\
\text { Coefficients }\end{array}$ & $\mathrm{t}$ & Sig. \\
\hline & $\mathrm{B}$ & Std. Error & Beta & & \\
\hline PSE & .358 & .143 & 0.337 & 4.323 & .005 \\
\hline PR & .940 & .085 & 1.020 & 8.845 & .005 \\
\hline SQ & .527 & .022 & 0.489 & 9.974 & 1.05 \\
\hline PV & .480 & .039 & 0.090 & 0.444 & .000 \\
\hline CON & .870 & .093 & 0.762 & 10.665 & .000 \\
\hline Dependent Variable: Perceived Usefulness
\end{tabular}

Table 6. Model Summary

\begin{tabular}{|c|c|c|c|c|}
\hline \multicolumn{5}{|c|}{ Summary of Regression Analysis } \\
\hline Model & $\mathrm{R}$ & R Square & Adjusted R Square & $\begin{array}{c}\text { Std. Error of the } \\
\text { Estimate }\end{array}$ \\
\hline 1 & $.970^{\mathrm{a}} .895$ & .8567 & .20875 & .45401 \\
\hline
\end{tabular}


Effect of Value, Administration Quality, Seen Worth and Administration Quality on Saw Value The table above shows that the model has Changed $\mathrm{R}$ square worth was 0.856 which portrays that the four factors can altogether represents 89.5 percent towards saw value. In addition the Cost has a beta of 0.940 with a t worth of 8.845 at importance level of 0.005 appearance positive critical impact on apparent helpfulness. Then, at that point, comes apparent self-adequacy with a beta of $0.358, \mathrm{t}$ worth of 4.323 at importance level of 0.005 introducing positive effect on subordinate variable. Different factors likewise showed positive effect. This way the substitute factors have been acknowledged appearance the meaning of model.

\section{FINDINGS AND RESULTS}

The outcomes portray that separated from administration quality which has non-huge connection any remaining variables that is seen self-viability, cost, see worth and comfort, and show importance towards the apparent helpfulness. Seen esteem show the most noteworthy impact then, at that point, trailed by others in diving request that is accommodation, cost and seen self-viability. Seen worth can be clarified as it shows the degree to which worth has been related by shopper keeping in view the cost alongside the work which is crucial for take benefit from the assistance just the usability. In this way it has been recorded that more noteworthy the apparent worth installs in the brain of shopper the more prominent the apparent value will be as they are interrelated to one another. Then again, accommodation go next to each other with the comprehension in utilizing the innovation can be called as energy or exertion put by buyer to use alongside the time it takes to utilize the innovation. The consequences of this review reliable with the examinations did by (Agarwal \& Prasad, 1999). The connection of cost with the apparent helpfulness portrays as delicate nature of purchaser abiding in a non-industrial country similarly in Pakistan and is more cognizant with regards to value they are prepared to pay forward e innovation. The effect of administration quality is inconsequential and the purpose for this is a direct result of many specialist co-ops it is cumber some to distinguish the best assistance until and except if some on ease belt beat the administrations given by all the specialist organizations and afterward can recognize the best specialist organization conveying quality help.

\section{CONCLUSIONS}

This exploration gives us genuine help and approves the discoveries of past research. Hypothetically, this review gives the ever-evolving connection between helpfulness of 5-G innovation with price, convenience, service quality, self-efficacy and value in Pakistan Currently; individuals are extremely keen on purchasing 5-G innovation gadgets and different apparatuses. Everybody needs to savor these compensations of the innovation. 5-G innovation opened up an inventive lifestyle for all innovation followers.

\section{RECOMMENDATIONS}

This exploration would not just help creation of 5-G shared systems administration innovation. This would likewise give speedy acknowledgment of any advancement of innovation applications. There are a few proposals dependent on the outcomes made for the gathered information:

- Gender inclinations are not prone not out of the ordinary the 5-G advances in Multan; hence, specialist co-ops ought to spur and draw in through expansion of significant worth in administrations.

- Age bunch additionally not liable to be embraced the 5-G innovation hence 5-G 
innovation mindfulness ought to be commercial center among the young people.

- Since proficient individuals are exceptionally profounder to take on innovation, yet as indicated by this examination they likewise denied 5-G innovation administration along these lines, this is disturbing in light of the fact that expert individuals can give more income for the organizations. Hence, 5-G innovation specialist co-ops need to accentuation on this space.

\section{LIMITATIONS}

Every one of the offices around 5-G advancements that have been assigned above need a gadget or apparatus like portable handset which can uphold this large number of constructions. Here we have designated the Multan city populace. That is the reason this examination can't be appropriate another region. This is the fundamental constraint to utilize this innovation in Multan as larger part of individuals would rather not buy rich or most recent gadgets.

\section{AUTHOR CONTRIBUTIONS}

Conceptualization: Muhammad Ismail, K. M. Anwarul Islam

Data Curation: Muhammad Ismail, Muhammad Zohaib

Formal Analysis: Muhammad Ismail, Muhammad Ijaz

Funding Acquisition: K. M. Anwarul Islam

Project Administration: Muhammad Ismail, K. M. Anwarul Islam

Software: Muhammad Ismail, Riaz Hussain, Zuhaib Hassan

Validation: Muhammad Ismail, Muhammad Yasir Tahir

Writing - Original Draft: Muhammad Ismail

Writing - Review \& Editing: K. M. Anwarul Islam

\section{CONFLICT OF INTEREST STATEMENT}

The authors declare that they have no competing interests.

\section{ACKNOWLEDGEMENT}

All authors contributed equally to the conception and design of the study

\section{REFERENCES}

Adams, D. A., Nelson, R. R., \& Todd, P. A. (1992). Perceived usefulness, ease of use, and usage of information technology: A replication. MIS quarterly, 16(2), 227-247.

Agarwal, R., \& Prasad, J. (1999). Are individual differences germane to the acceptance of new information technologies?. Decision sciences, 30(2), 361-391.

Ajzen, I., \& Fishbein, M. (1980). Understanding Attitudes and Predicting Social Behavior, Prentice-Hall, Englewood Cliffs, NJ.

Allsop, D. T., Bassett, B. R., \& Hoskins, J. A. (2007). Word-of-mouth research: principles and applications. Journal of advertising research, 47(4), 398-411.

Alch, M. L. (2000). The echo-boom generation: A growing force in American society. The Futurist, 34(5), 42-46. 
Ajzen, I., \& Fishbein, M. (1975). Belief, attitude, intention and behavior: an introduction to theory and research. Addsion-Wesley. Reading MA.

Buellingen, F., \& Woerter, M. (2004). Development perspectives, firm strategies and applications in mobile commerce. Journal of Business Research, 57(12), 1402-1408.

Compeau, D. R., \& Higgins, C. A. (1995a). Computer self-efficacy: Development of a measure and initial test. MIS quarterly, 19(2), 189-211.

Compeau, D. R., \& Higgins, C. A. (1995b). Application of social cognitive theory to training for computer skills. Information systems research, 6(2), 118-143.

Davis, F. D., Bagozzi, R. P., \& Warshaw, P. R. (1989). User acceptance of computer technology: A comparison of two theoretical models. Management science, 35(8), 982-1003.

Davis, F. D. (1985). A technology acceptance model for empirically testing new end-user information systems: Theory and results (Doctoral dissertation, Massachusetts Institute of Technology).

Ghinea, G., \& Angelides, M. C. (2004). A user perspective of quality of service in m-commerce. Multimedia Tools and Applications, 22(2), 187-206.

Hill, T., Smith, N. D., \& Mann, M. F. (1987). Role of efficacy expectations in predicting the decision to use advanced technologies: The case of computers. Journal of applied psychology, 72(2), 307.

Kumar, S. (2004). Mobile communications: global trends in the 21st century. International Journal of Mobile Communications, 2(1), 67-86.

Lee, S., Lee, S., \& Park, Y. (2007). A prediction model for success of services in e-commerce using decision tree: E-customer's attitude towards online service. Expert Systems with Applications, 33(3), 572-581.

Lee, Y.J. (2003). An examination of the determinants of customer loyalty in mobile commerce contexts. Information \& Management, 43(3), 271-82.

Liang, T. P., \& Wei, C. P. (2004). Introduction to the special issue: Mobile commerce applications. International journal of electronic commerce, 8(3), 7-17.

Mun, Y. Y., \& Hwang, Y. (2003). Predicting the use of web-based information systems: selfefficacy, enjoyment, learning goal orientation, and the technology acceptance model. International journal of human-computer studies, 59(4), 431-449.

Robinson, H., Wysocka, A., \& Hand, C. (2007). Internet advertising effectiveness: the effect of design on click-through rates for banner ads. International Journal of Advertising, 26(4), 527-541. 
Yu, J., Ha, I., Choi, M., \& Rho, J. (2005). Extending the TAM for at commerce. Information \& management, 42(7), 965-976.

Zhang, X., \& Prybutok, V. R. (2005). A consumer perspective of e-service quality. IEEE transactions on Engineering Management, 52(4), 461-477.

\section{Copyrights}

Copyright for this article is retained by the author(s), with first publication rights granted to the journal. This is an open-access article distributed under the terms and conditions of the Creative Commons Attribution license (https//creativecommons.org/licenses/by/4.0). 